\title{
Doxepin Hydrochloride
}

National Cancer Institute

\section{Source}

National Cancer Institute. Doxepin Hydrochloride. NCI Thesaurus. Code C29006.

A dibenzoxepin derivative and tricyclic antidepressant with antipruritic and sedative activities. Doxepin blocks the reuptake of norepinephrine and serotonin into presynaptic terminals thereby prolonging the availability of the monoaminergic neurotransmitters within the synaptic cleft and enhancing their action leading to sedative effects. Doxepin also has antagonistic effects on histamine ( $\mathrm{H} 1$ and $\mathrm{H} 2), 5-\mathrm{HT} 2$, alpha-1 adrenergic, and muscarinic receptors. The antipruritic effect of this agent is the result mediated through inhibition of histamine receptors. 